\title{
Effect of mechanization level on manpower needs in forestry
}

\author{
Urszula Bluszkowska $\bowtie$, Tomasz Nurek
}

Warsaw University of Life Sciences, Faculty of Production Engineering, Nowoursynowska 164, 02-787 Warsaw, Poland, phone: +48 22 5934520, e-mail: urszula_bluszkowska@sggw.pl

\section{Abstract}

High work consumption in forest operations is above all the result of the character and task realization mode in works undertaken in forestry. Development of mechanization in forest management activities allows to considerably decrease manpower needs. In the present study, there were analyzed the possibilities of reduction of work consumption by improving the mechanization level of forest works. The method was developed to consider the following assessments: 1) variant $\mathrm{W} 1$ - basic option comprising factual work consumption values in works carried out on the area administered by the Regional Directorate of State Forests (RDLP); 2) W2 - showing the effect of 25\% upgrade of works to a higher level of mechanization; 3) W3 - showing the effect of 50\% upgrade of works to a higher level of mechanization; 4) W4 - comprising analogous calculations to those in variant W1, but work consumption upgrading was $75 \%$. Simulation calculations revealed considerable differences in needs for labor of different categories of forest workers. On the other hand, with increasing mechanization level, there increase the demands concerning worker qualifications, e.g. a harvester operator must be trained for about 2 years, and the training has to include both simulator exercises (first using software and next - harvester simulator) and field work under supervision to gain sufficient experience. The introduction of higher levels of mechanization into forest operations, and hence considerable reduction of jobs for unqualified workers who are replaced by qualified employees, can help decreasing work consumption in forest operations.

\section{KeY WORDS}

seasonality, production works in forestry, forest work mechanization, work consumption, seasonal employment, forest worker

\section{INTRODUCTION}

Numerous works performed in forestry can be characterized by the specific and precisely defined time schedule dictated by forest vegetation conditions. These circumstances lead to seasonality of forestry operations. The concept of "seasonal work" has not been defined neither in Poland's Labor Code (2010) nor in the Act of 20 April 2004 on Employment Promotion and Labor Market Institutions (Dziennik Ustaw 2004). Thus, the common use of this term has to be contemplated. The meaning of the word "seasonal" is defined in the Polish language dictionary (Słownik języka polskiego 2007) and in free translation it connotes: "inherent to a sea- 
son, associated with a given season of the year, working or active in a given season, e.g. seasonal employees or workers". Employers of seasonal labor force are usually interested in quick engagement of available supplementary workers, and not too complicated separation with them soon after (Januszewska 2007). Seasonal employment represents one of the types of temporary employment and is included in the group of so called atypical forms of employment (Karpińska-Mizielińska and Smuga 2008).

Seasonal employing is not easy, in particular for the owners of forestry companies realizing management tasks on forest areas. It can become burdensome, first of all due to labor shortages. Young men "escape" from rural areas to big cities or else abroad. Seasonal employment to a big extend influences employee's attitude expressed by no integration with the company, first of all for the reason that the perspective for further collaboration hardly exists. Regrettably, seasonal workers are most often recruited from social groups with a low education level, which negatively influences their income as well as social position. Furthermore, unskilled workers employed for performing simple works are not competitive on the labor market. Exclusivity of the forest worker category when compared to other physical professions is also visible at the socio-cultural level. Forest workers create a specific subculture group which is somewhat marginalized, therefore, forest worker profession is barely attractive, and consequently, it is difficult to hire people interested in this kind of career (Labor Code 2010). Seasonal employment is associated with periodicity and indicates transitional arrangement. Permanent employees have an opportunity to build the company's organizational structure (Nogalski 1998). Permanent job encourages employees to further selfdevelopment, at the same time stimulates the employer to invest into education of own employees and improvement of their skills. Such approach to a big extent guaranties the stability of the company on the market.

The analysis of the time schedule of factual performance of the work in forestry is of importance both in operation planning and deciding on work durability, and these are connected with the possibilities of work specialization (Patalas 1987). The aim of the present study was to determine differences in manpower needs depending on mechanization levels of forest operations as well as development of a method to mitigate the ef- fect of work seasonality. One of the solutions for difficulties associated with work seasonality can be work mechanization. Changing the method of task realization can result in reduction of manpower needs and shorten the time of work performance. Consequently, it can be expected that accumulation of work on a given area will not cause an increase of manpower needs at the same time. The knowledge gained could allow for improvement of forest operation planning in such way that negative effects, especially from the viewpoint of seasonal employer, attributable to changeability of manpower needs, could be decreased.

\section{MAterial AND MEthodS}

Data on manpower needs were obtained from the Regional Directorate of State Forests in Szczecin and the descriptive database of State Forests - SILP. The analysis concerned the realization of forest operations in 2005-2008. There also were used figures from the Catalogue of time standards for forest works performed in forest management practice and the Catalogue of time standards for works performed in timber harvesting with the use of mechanical means. For calculations, there were distinguished 5 groups of forestry works: timber harvesting, afforestation/reforestation activities, forest tending, as well as transportation and nursery works.

Input data obtained from SILP database and concerning task realization at forest district level were as follows:

$Q o_{i}$ - operation scale $i$ [j.m - measurement unit], $\mathrm{po}_{i}$ - operation work consumption $i$ [man-hour/j.m.], $\mathrm{Po}_{i}$ - operation total work consumption $i$ [man-hour].

A preliminary analysis of database records showed that the values for the above 3 parameters were not always available. However, in all cases it was possible to calculate lacking data based on the following relationship:

$$
P o_{i}=Q o_{i} \times p o_{i}
$$

In the database, the forest operations analyzed were labeled according to the terminology used in the Catalogues of (...) standards (...), which allowed designating the works (operations) carried out in forestry into the above 5 groups of work. The next step of the analysis 
was the calculation of manpower needs for each of these groups: timber harvesting $(P O Z)$, afforestation/reforestation $(O D N)$, tending $(P L G)$, nursery $(S Z K)$ transportation (extraction, $Z R Y W$ ).

The following formulas were used:

$$
\begin{aligned}
P^{P O Z} & =\sum_{i=1}^{n} P o_{i}^{P O Z} \\
P^{O D N} & =\sum_{i=1}^{n} P o_{i}^{O D N} \\
P^{P L G} & =\sum_{i=1}^{n} P o_{i}^{P L G} \\
P^{S Z K} & =\sum_{i=1}^{n} P o_{i}^{S Z K} \\
P^{Z R Y W} & =\sum_{i=1}^{n} P o_{i}^{Z R Y W}
\end{aligned}
$$

where:

$P^{P O Z}$ - total work consumption for all works in $P O Z$ operations (same for $O D N, P L G, \mathrm{ZRYW}$ ),

$P o_{i}^{P O Z}$ - total work consumption i for POZ (same for $O D N, P L G, Z R Y W)$,

$n-\quad$ the number of operations in a given category of operations.

The above calculations allowed only for gaining knowledge on manpower needs for each group of forest works but gave no information on the issues concerning the demand for employees. As already said, the Catalogues of (...) standards (...) provide the classification of works in forestry (activities) with reference to the mode of their realization as well as information on work consumption for each activity depending on a mechanization level involved in work performance. Based on information in the Catalogues of (...) stand$\operatorname{ards}(. .$.$) , there were distinguished three categories of$ forestry works:

- G1 - works performed manually - simple works performed with the use of manual tools;

- G2 - works performed with the use of simple mechanical tools;

- G3 - works performed with the use of self-propelled machinery - tractor units and specialized machines.

Based on the above classification, three categories of workers were distinguished:
- R1 - employees realizing the tasks from G1 category; workers with basic skills allowing for performance of work with manually operated tools (e.g. hoe, shovel, hook, skidding grip, ax, machete, stick);

- R2 - employees realizing the tasks from G2 forestry work category; workers with skills allowing for performance of forestry works with the use of portable manually operated tools (e.g. petrol chain saw, mower, knapsack sprayer, manual soil drill);

- R3 - employees realizing the tasks from G3 forestry work category; qualified workers - trained in operating self- propelled machinery used in forestry, operators of: tractors, multi-operation forest machinery as well as construction and road equipment.

It was assumed that detailed analyses on manpower needs for specific categories of employees will be carried out only for dominant forestry work groups. It was decided that a threshold for excluding a given group of forestry works from detailed analyses would be its $5 \%$ share in the total annual manpower need in a given forest district. The results of calculations showed that manpower needs were the highest for three groups of forestry works: timber harvesting, afforestation/reforestation and tending. In the years 2005-2008, work consumption for timber harvesting was the highest and constituted almost $50 \%$ of the total work input. At the same time, work consumption for forest tending operations was $25 \%$ of the total work input and that of afforestation/reforestation operations was $20 \%$. Nursery and transportation works constituted together $5 \%$ of all forestry works carried out during each year of observations. The low share of nursery and transportation works was the reason why they were not taken into consideration in further analyses.

Simulation assessments were carried out for 4 selected forest districts within the area under administration of the Regional Directorate of State Forests in Szczecin (RDLP Szczecin). The forest districts were selected based on 2 criteria: criterion of significance and criterion of geographical situation. The criterion of significance determined the selection of the forest districts where the share of the work categories analyzed was statistically significant when compared with every part of RDLP Szczecin. The interval of significance was determined based on the uniform measure allowing for defining statistical differences. The meas- 
ure was constructed based on the value of the share of each work category in forest operations carried out at a scale of the whole RDLP Szczecin area annually. The relevant values were treated as the mean values for statistical comparisons of work category shares at a forest district level. Next, there had to be defined the interval of differences with no statistical significance. For that reason, in the analyses, there was introduced a model of standardized distinction from the mean share of a given work category at a RDLP level when compared to that at a forest district level. The deviation was determined as $\pm 20 \%$. Based on the results of the analysis of factual data (absolute values), it was decided that for the needs of the present study, the assumed standard deviation $20 \%$ would allow for the assessment of significant and not significant values.

Based on the above approach, there were established the intervals of no-significance for the differences between the work categories analyzed at a forest district level in the years of the study, following the formulas below:

- determination of the index of decreasing or increasing of the value of a share of a given work category at the RDLP scale

$$
W_{\text {w.u. }}=U_{i} \times 0.2 \quad \text { [p.p.] }
$$

where:

$W_{\text {w.u. }}$ - index of increasing or decreasing of share value,

$U_{i} \quad$ - percentage share of work category $(\mathrm{G} 1, \mathrm{G} 2$, G3) at RDLP scale,

0.2 - standard deviation value,

p.p. - percent points.

- calculation of the interval of not significant differences between forest districts in terms of work categories:

$$
\begin{array}{ll}
U x_{d}=U_{i}-W_{\text {w.u. }} & {[\%]} \\
U x_{g}=U_{i}+W_{\text {w.u. }} & {[\%]}
\end{array}
$$

where:

$U x_{d}$ - lower interval limit,

$U x_{g}$ - upper interval limit,

$U_{i}$ - percentage share of work category (G1, G2, G3) at RDST scale,

$W_{w . u}$ - index of increasing or decreasing of the share [percent points].
The intervals of not significant differences are presented in table 1.

Table 1. Share of work categories and intervals of not significant differences between forest districts under

\begin{tabular}{|c|c|c|c|c|c|c|}
\hline \multirow{3}{*}{ Year } & \multicolumn{2}{|c|}{$\begin{array}{c}\text { Timber } \\
\text { harvesting }\end{array}$} & \multicolumn{2}{|c|}{$\begin{array}{l}\text { Afforestation/ } \\
\text { reforestation }\end{array}$} & \multicolumn{2}{|c|}{ Tending } \\
\hline & \multirow{2}{*}{$\begin{array}{c}\text { Share } \\
\text { on } \\
\text { RDLP } \\
\text { scale } \\
{[\%]}\end{array}$} & $\begin{array}{c}\text { lower } \\
\text { limit }\end{array}$ & \multirow{2}{*}{$\begin{array}{c}\text { Share } \\
\text { on } \\
\text { RDLP } \\
\text { scale } \\
{[\%]}\end{array}$} & \multirow{2}{*}{$\begin{array}{c}\text { lower } \\
\text { limit }\end{array}$} & \multirow{2}{*}{$\begin{array}{l}\text { Share } \\
\text { on } \\
\text { RDLP } \\
\text { scale } \\
{[\%]}\end{array}$} & \multirow{2}{*}{$\begin{array}{c}\text { lower } \\
\text { limit }\end{array}$} \\
\hline & & $\begin{array}{c}\text { upper } \\
\text { limit }\end{array}$ & & & & \\
\hline \multirow{2}{*}{2005} & \multirow{2}{*}{44.5} & 35.6 & \multirow{2}{*}{21.0} & 16.8 & \multirow{2}{*}{29.7} & 23.8 \\
\hline & & $\overline{53.4}$ & & 25.2 & & 35.6 \\
\hline \multirow{2}{*}{2006} & \multirow{2}{*}{46.8} & 37.4 & \multirow{2}{*}{20.2} & 16.2 & \multirow{2}{*}{27.9} & 22.3 \\
\hline & & 56.5 & & 24.2 & & 33.5 \\
\hline \multirow{2}{*}{2007} & \multirow{2}{*}{48.3} & 38.6 & \multirow{2}{*}{20.3} & 16.2 & \multirow{2}{*}{25.5} & 20.4 \\
\hline & & 50.0 & & 24.4 & & $\begin{array}{l}30.6 \\
\end{array}$ \\
\hline \multirow{2}{*}{2008} & \multirow{2}{*}{46.6} & 37.3 & \multirow{2}{*}{23.3} & 18.6 & \multirow{2}{*}{22.5} & 18.0 \\
\hline & & $\overline{55.9}$ & & $\overline{28.0}$ & & $\overline{27.0}$ \\
\hline
\end{tabular}
administration of Regional Directorate of State Forests (RDLP) in Szczecin in 2005-2008

Source: original research.

Out of 35 forest districts in RDLP Szczecin, there were distinguished the forest districts which most often showed such values for the share of the three work categories analyzed which could be included into the interval assumed as that with not significant differences. In the next step of forest districts selection, there was considered the criterion of geographical situation which allowed the choice of the forest districts located at northern, southern, western and eastern edges of the area administered by RDLP Szczecin. These were 4 forest districts: Chojna, Drawno, Rokita and Sulęcin Forest Districts. In the districts selected, the work input for operations carried out at the same level of mechanization (G1, G2, G3) was summed up. According to subject literature, the issue of a high level of work consumption in forest operations is first of all due to not sufficient enough level of mechanization. The Catalogues of (...) standards (...) indicate that technological operations resulting in similar effects can be performed at different levels of mechanization. The possibility of work performance using different means which is associated with changing work consumption levels is of big importance in organization of forestry works. For example, Nurek 
(2011) points out that similar silviculture results can be achieved when work is performed during different time durations and using different technologies.

Table 2. Examples of work consumption values in forest operations

\begin{tabular}{|l|c|l|c|}
\hline \multicolumn{2}{|c|}{ Manual works } & \multicolumn{2}{c|}{$\begin{array}{c}\text { Works carried out with } \\
\text { tools fixed to wheeled } \\
\text { tractors }\end{array}$} \\
\hline $\begin{array}{l}\text { Weeding in rows } \\
\text { or strips at seedling } \\
\text { emergence [13] }\end{array}$ & $\begin{array}{c}3.30-4.20 \\
\text { man-hour/ } \\
\text { are }\end{array}$ & $\begin{array}{l}\text { soil ripping } \\
\text { using multi- } \\
\text { row weeder } \\
{[237]}\end{array}$ & $\begin{array}{c}0.08-0.15 \\
\text { man-hour/ } \\
\text { are }\end{array}$ \\
\hline $\begin{array}{l}\text { Weed mowing } \\
\text { in afforestation / } \\
\text { reforestation areas } \\
\text { and decreasing } \\
\text { seedling density } \\
\text { in derivative } \\
\text { cultivation [153] }\end{array}$ & $\begin{array}{c}36.0-57.0 \\
\text { man-hour/ } \\
\text { ha }\end{array}$ & $\begin{array}{l}\text { Maintenance } \\
\text { works in } \\
\text { between rows } \\
{[271]}\end{array}$ & $\begin{array}{c}2.00-4.50 \\
\text { man-hour/ } \\
\text { ha }\end{array}$ \\
\hline $\begin{array}{l}\text { Planting of 2-3 } \\
\text { year old nursery } \\
\text { seedlings [5] }\end{array}$ & $\begin{array}{l}\text { 5.70-6.30 } \\
\text { man-hour/ } \\
1000 \text { pcs. }\end{array}$ & $\begin{array}{l}\text { planting of } \\
\text { seedlings } \\
\text { using one- } \\
\text { row planter } \\
{[238]}\end{array}$ & $\begin{array}{c}\text { man-hour/ } \\
\text { 1000 m }\end{array}$ \\
\hline
\end{tabular}

Source: T. Nurek [2011].

As the above author reports, in the case of works associated with weeding in afforestation/reforestation areas, manual performance of the work demands 40 fold higher work input when compared to realization of the same task using mechanical means. Other examples from table 2 show similar relationships. For the analyses presented in this study, there was determined the reduction factor per unit effort 1 , expressed as the ratio of work consumption at a higher mechanization level and that for work performed manually.
The possibility of reduction of manpower needs in the work categories studied was analyzed based on evaluation of work consumption in the four following variants: 1) variant $\mathrm{W} 1$, basic option comprising factual work consumption values in works carried out within RDLP. 2) W2 - for this variant it was assumed that $25 \%$ of works would be upgraded to a higher level of mechanization, thus, work input from the category G1 was transferred into G2. The calculations showed that work consumption in G1 category decreased, whereas in G2 - it increased. Similar relationship was observed when work input if was transferred from G2 to G3 - if work was possible to be performed at a higher mechanization level. 3) Variant W3 comprised analogous calculations to those in variant W2, however, in W3 option, work consumption upgrading was 50\%.4) Variant W4 comprised analogous calculations to those in variant $\mathrm{W} 1$ but work consumption upgrading was $75 \%$. The values for work consumption were calculated following the formulas below:

$$
P_{R i}^{\prime}=\lambda \alpha_{(i-1)} P_{R(i-1)}+\left(1-\alpha_{i}\right) P_{R i}
$$

where:

$P_{R i}^{\prime}-$ work consumption in tasks realized by employees from $R_{i}$ group (from Gi category) in all variants,

$P_{R i}$ - work consumption in tasks realized by employees from $R_{i}$ group (from Gi category) in basic variant $-\mathrm{W} 0$,

$\lambda$ - reduction factor per unit effort,

$\alpha_{i}$-index of enhancement of mechanization level expressed in percent values of initial work consumption upgraded to higher level of mechanization.

The values of indexes for the variants analyzed are presented in table 3 .

Table 3. Parameters of variants in simulation calculations

\begin{tabular}{|c|c|c|c|c|c|c|c|c|c|c|c|c|}
\hline \multirow{3}{*}{$\begin{array}{l}\text { Worker } \\
\text { category }\end{array}$} & \multicolumn{12}{|c|}{ Variant } \\
\hline & \multicolumn{3}{|c|}{ W1 } & \multicolumn{3}{|c|}{ W2 } & \multicolumn{3}{|c|}{ W3 } & \multicolumn{3}{|c|}{ W4 } \\
\hline & $\alpha_{(i-1)}$ & $\alpha_{i}$ & 1 & $\alpha_{(i-1)}$ & $\alpha_{i}$ & 1 & $\alpha_{(i-1)}$ & $\alpha_{i}$ & 1 & $\alpha_{(i-1)}$ & $\alpha_{i}$ & 1 \\
\hline $\mathrm{R} 1$ & 0.0 & 0.0 & 0.0 & 0.00 & 0.25 & 0.0 & 0.0 & 0.5 & 0.0 & 0.00 & 0.75 & 0.0 \\
\hline $\mathrm{R} 2$ & 0.0 & 0.0 & 0.0 & 0.25 & 0.25 & 0.2 & 0.5 & 0.5 & 0.2 & 0.75 & 0.75 & 0.2 \\
\hline R3 & 0.0 & 0.0 & 0.0 & 0.25 & 0.0 & 0.2 & 0.5 & 0.0 & 0.2 & 0.75 & 0.0 & 0.2 \\
\hline
\end{tabular}

Source: original research. 
A decrease of manpower needs in the work categories with the highest needs is one of the tasks of the owners of the companies undertaking forest operations.

\section{RESULTS}

In 2005-2008, there were observed similar levels of work input in the three distinguished categories of workers performing forest operations in 35 forest districts situated within the area of the Regional Directorate of State Forests in Szczecin. Therefore, the variant analysis was done just for the Forest District Chojna as an example, based on data concerning the year 2008. Table 4 presents the results of simulation calculations for each of the distinguished categories of workers (R1, R2, R3). The results comprise the sum of work consumption values for 3 types of forest operations: timber harvesting, afforestation/reforestation and forest tending.

Table 4 shows considerable disproportions, especially noticeable in variant W1. In this case, work consumption was accumulated in R2 category of workers and amounted to $62 \%$ of the total work consumption. Work consumption for R1 and R3 categories of forest workers was: $24.2 \%$ and $14.2 \%$, respectively.

In R1 worker category, in each of the variants analyzed, there was observed a decrease of work consumption. The values obtained were $75 \%, 50 \%$ and $25 \%$ of initial work consumption. Implementation of other vari- ants in this category showed a possibility of a considerable decrease of work consumption.

The results of simulation analyses in $\mathrm{R} 2$ worker category were somewhat different. Two factors influenced the results obtained for this worker category. The first one was upgrading a part of works to a higher mechanization level. The second factor was insertion of works from R1 worker category in R2. However, it has to be noted that upgrading from G1 category of work to G2 was linked with increasing a mechanization level connected with the reduction of labor intensity in the relevant work categories. In accordance with $1=0.2$, in simulation calculations, there was assumed 5-fold decrease of work consumption. As presented in table 4, in G2 category, there was observed a decrease of labor intensity in all the variants analyzed: by $23 \%$ in variant $\mathrm{W} 2,46.1 \%$, in W3, and in W4 - by $69.1 \%$. In G3 work category, the one with the highest mechanization level, there was observed a change associated only with one of the above described factors. The value of labor intensity was increased only in case of upgrading works from G2 to G3 (taking into consideration 1 factor). There was no possibility to upgrade works from G3 category to an upper level, given that taking into account the current status of forest technology, there was no possibility to more advanced upgrading the mechanization level of forest operations. The last three rows of table 4 show percentage change between the initial value of work consumption and that resulting from application of subsequent variants. A decrease of manpower needs for workers

Table 4. Work consumption in realization of tasks by categories of forest workers when analyzed in variants W2, W3, W4

\begin{tabular}{|c|c|c|c|c|c|}
\hline & \multirow{2}{*}{$\begin{array}{l}\text { Worker } \\
\text { category }\end{array}$} & \multirow{2}{*}{$\begin{array}{c}\text { W1 - basic } \\
\text { variant } \\
\text { [man-hour }]\end{array}$} & \multicolumn{3}{|c|}{$\begin{array}{l}\text { Variant of percentage decrease of work } \\
\text { consumption [man-hour] }\end{array}$} \\
\hline & & & $\mathrm{W} 2$ & W3 & W4 \\
\hline \multirow{3}{*}{ Factual work consumption } & $\mathrm{R} 1$ & 81317.0 & - & - & - \\
\hline & $\mathrm{R} 2$ & 207106.7 & - & - & - \\
\hline & R3 & 47723.4 & - & - & - \\
\hline \multirow{3}{*}{ Work consumption calculated in variants } & $\mathrm{R} 1$ & 0.0 & 63389.25 & 42259.50 & 21129.75 \\
\hline & $\mathrm{R} 2$ & 0.0 & 159395.90 & 111685.10 & 63974.20 \\
\hline & R3 & 0.0 & 58078.70 & 68434.10 & 78789.40 \\
\hline \multirow{3}{*}{ Changes due to application of variants } & $\mathrm{R} 1$ & - & $75.0 \%$ & $50.0 \%$ & $25.0 \%$ \\
\hline & $\mathrm{R} 2$ & - & $77.0 \%$ & $53.9 \%$ & $30.9 \%$ \\
\hline & R3 & - & $121.9 \%$ & $143.4 \%$ & $165.1 \%$ \\
\hline
\end{tabular}

Source: original research. 
in R1 category was a direct result of upgrading works from G1 category (basic variant) and relocating the related value of work consumption into the category G2. The value was determined by the variant type applied $-\mathrm{W} 2, \mathrm{~W} 3, \mathrm{~W} 4$. As a result of using the variants, in G2 category as well as in G1, there were observed decreases in the obtained work consumption values when compared to those initial. The decrease obtained was lower than expected. This was due to the fact that the value of work consumption for $\mathrm{G} 2$ category was increased by the value of labor intensity relocated from G1 category. The application of the variants allowed for decreasing work consumption by 2 percent points in W2 variant, 3.9 percent points in W3variant and 5.9 percent points in W4. As shown by the above results, both for R1 and R2 worker category, there were observed expected decreases of work consumption. The results for R3 worker category are different. For this category, in all the variants tested, there was observed a considerable increase of work consumption. In W2 variant it was $21.9 \%$ of the initial work consumption value, in W3 - 143.4\%, and in W4 it was even 1.5 -fold higher - $165.1 \%$. Such evocative increase was due to two factors. The category G3 had the highest level of work mechanization, therefore, upgrading to higher mechanization levels was not possible, and consequently the initial value of work consumption was not decreased. However, work consumption value in G3 category was increased as a consequence of relocating work consumption from G2 into G3. Such a considerable increase in G3 category was a result of high value of initial work consumption. In G2 category work consumption was almost 4.5 -fold higher than that in G3.

\section{Conclusions AND Discussion}

The method presented is of open nature, i.e. the number of forest districts entered in the variant models as well as that of activities and modes of work can be increased or decreased. The results presented stem from the prerequisite to analyze specific case study: here, carried out based on data concerning a given area, selected categories of forestry works which were performed within a specific timeframe. Analogous analyses conducted on other forest areas may possibly give different results. The results obtained in the present study are hardly reflected in subject literature.
The increase of a mechanization level of works results in a decrease of manpower needs. Depending on work types, this reduction can be from a few times to even more than a dozen times. Consequently, there can be expected a decrease in manpower needs for unqualified workers. At the same time, an increase of manpower needs for qualified workers (e.g. operators of handheld mobile machinery, of tractors with specialized aggregate machines or else of self-propelled machinery). Furthermore, manpower needs for qualified workers will be considerably lower when compared to those for unqualified workers.

The simulation calculations performed confirmed that e.g. 50\% upgrading of works (based on man-hours) towards a higher mechanization level led to $50 \%$ decrease of manpower needs for workers with the lowest skills (R1), almost $54 \%$ - for the workers from R2 category and the increase of manpower needs for the workers with the highest qualifications (R3 category) by $43.4 \%$. As a result, the smaller number of workers can be engaged in the realization of forestry tasks on a given area, especially of those unskilled. The decrease of work consumption means the increase of work efficiency and constitutes the factor improving work planning towards decreasing negative effects of seasonality of the demand for a workforce.

The method presented allows for changing the values of 1 and $\alpha$ indexes. This gives the basis for assuming the method as an all-purpose one.

\section{References}

Błuszkowska U. 2013. Czynniki determinujące wielkość i strukturę zatrudnienia robotników realizujących zadania produkcyjne w leśnictwie. $\mathrm{Ph}$. D. thesis, Faculty of Forestry,Warsaw University of Life Sciences, Poland.

Brzózko J., Dybcio M. 2007. Umiejętności, kwalifikacje i doświadczenie operatorów a wydajność pracy specjalistycznych maszyn leśnych (in Polish). Technika Rolnicza, Ogrodnicza, Leśna, 3, 5-7.

Jabłoński K. 2006. Optymalizacja sposobów realizacji procesu technologicznego pozyskiwania i zrywki drewna na określonym obszarze leśnym. Roczniki AR Poznań, Rozprawy Naukowe, 378, 5-89. 
Januszewska M. 2007. Ławo zatrudnić i zwolnić pracowników sezonowych. Rzeczpospolita, 166 (7763).

Karpińska-Mizielińska W., Smuga T. 2008. Zatrudnienie sezonowe w sektorze turystyki. Wnioski z badań. Gospodarka Narodowa, 3, 173.

Kocel J. 2013. Wyposażenie firm w środki techniczne i ich wykorzystanie. In: Firmy leśne w Polsce. Centrum Informacyjne Lasów Państwowych, Warszawa, 155-158.

Kodeks pracy. 2010. Warszawa.

Nogalski B. 1998. Kultura organizacyjna. Duch organizacji. Oficyna Wydawnicza Ośrodka Postępu Organizacyjnego, Bydgoszcz, 305-306.

Nurek T. 2011. Struktura zatrudnienia w zakładach usług leśnych a poziom mechanizacji. Technika Rolnicza, Ogrodnicza, Leśna, 6, 4-5.

Patalas Z. 1987. Zagadnienia organizacji prac leśnych. Warszawa, 220-223.

Słownik języka polskiego. 2003. PWN, Warszawa.

Ustawa o promocji zatrudnienia i instytucjach rynku pracy. 2004. Dz. U. z 2008 r., nr 69, poz. 415.
Zarządzenie nr 99 Dyrektora Generalnego Lasów Państwowych. 2008. Katalog norm czasu dla prac leśnych wykonywanych przy zrywce drewna środkami mechanicznymi. Ośrodek Rozwojowo-Wdrożeniowy Lasów Państwowych w Bedoniu.

Zarządzenie nr 99 Dyrektora Generalnego Lasów Państwowych. 2008. Katalog norm czasu dla prac leśnych wykonywanych w pozyskaniu drewna. Ośrodek Rozwojowo-Wdrożeniowy Lasów Państwowych w Bedoniu.

Zarządzenie nr 99 Dyrektora Generalnego Lasów Państwowych. 2008. Katalog norm czasu dla prac leśnych wykonywanych $\mathrm{w}$ zagospodarowaniu lasu. Ośrodek Rozwojowo-Wdrożeniowy Lasów Państwowych w Bedoniu.

Zychowicz W., Gendek A., Skarżyński J., Wójcik K., Aniszewska M., Maciak A. 2010. Wyposażenie w pilarki spalinowe zakładów usług leśnych działających w Regionalnej Dyrekcji Lasów Państwowych w Olsztynie. Parce Komisji Nauk Rolniczych, Leśnych i Weterynaryjnych PAU, 14, 229-236. 